\title{
Deep Adventitial Inked Margin
}

National Cancer Institute

\section{Source}

National Cancer Institute. Deep Adventitial Inked Margin. NCI Thesaurus. Code C96174.

An inked deep surgical marg in that indicates the outermost layer of connective tissue covering an organ or a vessel has been identified as an area warranting further study. 